Artikkel til Kirke og Kultur

Versjon 26.09.2017

\title{
Populærprotestanten: Nøysomhet uten gudsfrykt
}

Nesten fem århundrer med statlig lutherdom har satt store avtrykk på norsk kultur. Årets reformasjonsjubileum har gitt anledning til grundige analyser av dypstrukturene i denne protestantiske påvirkningen. Men det kan også være interessant å gjøre en mindre dyptpløyende analyse, å bevege seg på protestantismens overflate, ikke for å jakte på dens kulturformende kraft, men snarere for å se etter den populære oppfatningen av protestantismen. I denne lille unders $\varnothing$ kelsen spør jeg etter hvordan klisjeen «protestantisk» og «protestant» brukes i norsk offentlighet: Hva inneholder den, hvilket arbeid utfører den og likner den det teologien og religionsvitenskapen forbinder med protestantisme?

«Klisjé» har en negativ klang, men klisjeen har også en funksjon. I trykkekunsten utførte den (på linje med stereotypien) et nyttig stykke arbeid. Den gjorde masseproduksjon av like eksemplarer raskere og enklere. Den språklige klisjeen appellerer til en uuttalt felles forståelse, et avtrykk eller minne. Undersøkelsen er altså en jakt på forestillingen om protestanten eller protestantismen slik den framstår utenfor den kirkelige, teologiske eller religionsvitenskapelige samtalen, som et avtrykk i kulturen. Jakten vil foregå i et utvalg på noe over hundre norske avistekster fra 2014 til 2017.

Med utgangspunkt i disse medietekstene er det fristende å utrope Karl Ove Knausgård til Norges fremste protestant. 'Om seg selv sier han i en åpen brevveksling under fotball-VM i Brasil i 2014:

\footnotetext{
Hvis noen hadde stilt meg følgende spørsmål: i hvilke romaner vil du helst leve? ville jeg ti av ti ganger ha valgt Fløgstads. Men om spørsmålet hadde vært i hvilke romaner du hører hjemme, ville jeg dessverre måtte ha sagt Solstads. Jeg er protestant langt inn i beinmargen, jeg er en som nekter meg ting, som sier nei til ting, og om jeg liker å lese om det frodige, dampende, utadvendte, livlige folkelivet i verden, hvor overskuddet er av det menneskelige, og ikke av det materielle eller økonomiske, så er det ikke en verden jeg kan leve i, knapt nok oppholde meg i, jeg vender meg bort, lengter etter å være alene, klarer ikke å forholde meg til all denne generøsiteten og varmen.i
}

I tekstene jeg undersøker er ingen andre omtalt så ofte som «protestant», av seg selv og av andre, som Knausgård. Sitatet inneholder mye av det som viser seg å være typisk for den populære 
forestillingen om protestanten: Det å nekte seg noe, nøysomhet og nøkternhet og kontrasteringen av dette med det «frodige, dampende, utadvendte, livlige». Knausgårds tvetydige identifisering med det protestantiske - han skulle gjerne vært noe annet, men klarer ikke - er typisk. Den forbeholdne omfavnelsen av protestantismen aktualiserer spørsmålet om hva protestant-klisjeen gjør: Assosieres den med noe godt eller dårlig? Svaret er «begge deler», og det knytter seg ofte et ambivalent blikk på norsk kultur til bruken. Sist, men ikke minst, er eksemplet med Knausgård representativt fordi en profilert kulturpersonlighet står i sentrum. Protestantisme-klisjeen ser ut til å ha en særlig plass på avisenes kultursider og i feature-journalistikken, i bokomtaler, i lange analyserende tekster og i portrettintervjuer.

\section{Tekstutvalget}

For å gjøre jakten på forestillinger om protestanten og protestantismen praktisk gjennomførbar, har jeg sett på tekster fra papirutgavene av sju store norske aviser: Aftenposten, Dagbladet, Dagens Næringsliv, Dagsavisen, Klassekampen, Morgenbladet og VG.iii For å få et tilstrekkelig og oppdatert tilfang av relevante tekster har jeg sett på treårsperioden 1. april 2014 til 31. mars 2017.

Et aller første funn er at protestant-klisjeen ikke forekommer særlig hyppig. Materialet for undersøkelsen utgjør til sammen 107 avistekster der klisjeen forekommer. Tekstene er identifisert på denne måten: Søk i de nevnte avisene for den valgte perioden i det digitale avisarkivet Atekst (Retriever) etter "protestant*" gir treff i 580 tekster. ${ }^{\text {iv }}$ Søket fanger inn alle forekomster av «protestant/en/er/ene», «protestantisk(e)» og «protestantisme(n)». Et flertall av disse tekstene faller imidlertid utenfor interessefeltet og er sortert ut. I omkring sju prosent av tekstene brukes «protestant» om noen som protesterer, en ordbruk som er i tråd med Bokmålsordbokas definisjon, men som Aftenpostens språkspaltist og tidligere redaktør Per Egil Hegge likefullt mener er et eksempel på «begrepsforvirring». Da gjenstår 542 avistekster som på en eller annen måte omtaler protestanter og protestantisme. Siden interessen her er klisjeen, er det kun de tekstene som på en direkte måte beskriver eller karakteriserer protestanter/protestantismen eller som bruker minst ett av disse ordene som noe mer enn en helt konvensjonell merkelapp til å karakterisere noe eller noen, som er av interesse. I mer enn halvparten av tekstene blir de relevante ordene kun brukt til å betegne for eksempel en kirkebygning, en prest eller en folkegruppe i samtiden på en konvensjonell måte som ikke bringer klisjeen i forgrunnen. Av disse er så mye som en femdel relatert til NordIrland, men også Skottland, Nederland og USA er godt representert i tillegg til protestanter under fjernere himmelstrøk. I svært mange av disse tilfellene kontrasterer «protestant» eller «protestantisk» eksplisitt eller implisitt med «katolsk». Det samme gjelder 125 tekster som handler 
om europeisk historie. Etter denne utsorteringen står vi igjen med de 107 tekstene som oppfyller kriteriene og som altså er unders $\emptyset$ kt nærmere for å finne ut hvordan klisjeen «protestant», «protestantisme» eller «protestantisk» brukes i norske medier i dag.

Det kunne være interessant å gå nærmere inn på det bildet som tegnes av protestanter også i alle de tekstene som er valgt bort. Hvorfor brukes en betegnelse med opphav i den religiøse sfæren som betegnelse på folkegrupper i bestemte situasjoner, og hvordan brukes «protestantisk» sammenliknet med mer teologisk spesifikke betegnelser som «reformert» eller «luthersk»? Kanskje enda mer interessant: Er det et mønster i hvordan skillelinjen mellom protestantisk og katolsk trekkes opp i norske medietekster? Alt dette kan ha innvirkning også på den norske populær-protestanten, men i denne omgang har jeg latt det ligge.

Avistekstene danner naturligvis ikke et skarpstilt og helhetlig bildet av «protestanten». Jeg har ikke gjort noen analyse av hvorvidt det er systematiske forskjeller avisene imellom når det gjelder hvilke aspekter ved populærprotestanten de vektlegger, men det er verdt å merke seg at bruken av protestant-klisjeen ikke fordeler seg jevnt på de ulike mediene. Klassekampen utmerker seg som den mest protestant-interesserte avisa. Den leverer alene en tredel av alle tekstene i utvalget. Deretter følger Dagbladet med omkring 20 prosent og Morgenbladet (som bare har én utgivelse i uka) med omkring 15 prosent. Dagsavisen og VG kommer nederst på lista.

\section{Religionsvitenskapens og teologiens protestant}

Ett av formålene med undersøkelsen er å finne ut om populære forestillinger om «protestanten» likner det bildet som teologi og religionsvitenskap tegner. Hvis avstanden er stor, må akademias og kirkens representanter være ekstra oppmerksomme når de bruker de aktuelle begrepene i den brede offentlige samtalen. Ellers oppstår misforståelser når ordene skaper andre assosiasjoner hos mottakeren enn det avsenderen selv har i tankene.

Selv om religionsvitenskapen ikke tegner noe entydig bilde av protestanten eller protestantismen, går noen trekk igjen: Protestantismen vektlegger indre trosoverbevisning, den ser med en viss skepsis på fastlagte ytre uttrykk for religion (som for eksempel klesdrakt og ritualer), den er ektefølt og ikke minst selvvalgt. Peter Berger er blant dem som beskriver protestantismen slik. vi Han mener det er denne religionsformen som har best kår i vestlige samfunn. Olivier Roy tenker i samme baner og mener det er en tendens i moderne samfunn at ulike religiøse tradisjoner, gjennom myndighetenes styring og ved egen tilpasning, blir mer lik protestantisme, de «protestantiseres». vii 
Den selvvalgte og ektefølte religionen blir normen. I ideal-protestantens $\varnothing$ yne kleber det noe mindreverdig ved det å tilhøre en religion uten at man har gjort et aktivt valg.

Verken Roy eller Berger kommer utenom Max Weber når de vil beskrive protestantismen. Weber, danner, som vi skal se, i en forstand brua mellom forskningens protestantisme og den populære forståelsen av protestantens kjennetegn. Mens Webers velkjente tese om en sammenheng mellom protestantisme og kapitalismens framvekst av mange forskere for lengst regnes som tilbakevist, viii er den en sentral premissleverand $\emptyset r$ for mange som bruker protestantisme-klisjeen. Skjønt «velkjent» er neppe det rette ordet. Tvert imot er det ofte en overflatisk kjennskap til Weber som kommer til uttrykk i populære forestillinger. Antakelig er det mange som ikke har fått med seg at Webers tese handler om kalvinister og at han eksplisitt ekskluderer lutheranerne fra sin modell. ${ }^{\text {ix }}$ Predestinasjonslæren er en sentral drivkraft i Webers tese. Den har ikke hatt noen plass i luthersk tankegang, heller ikke blant de mest pietistisk anlagte som ellers deler mye tankegods med den reformerte grenen av protestantismen.

De færreste av de mange som mer eller mindre eksplisitt hinter til Weber når de bruker protestantisme-klisjeen later til å ha nyansene i hans tese klart for seg. En spaltist i Klassekampen ser på egne analyser med et skråblikk, men kunne nok talt på vegne av flere skribenter: Med innledningsordene «Hva ville Weber sagt?» tar han leseren med inn i Den protestantiske etikk før han avbryter seg selv: «Eller noe sånt. Jeg har aldre lest hele, bare bladd i Pax forlags pocketutgave (1995) $).{ }^{x}$

Mens religionsvitenskapen ser etter typiske kjennetegn ved protestantismen beskrevet utenfra, gir teologien og kirkene bud på hva protestantisme er sett fra innsiden. Det er nærmest umulig å destillere en teologisk forståelse av protestantisme til noen få ord. Likevel var det det Den norske kirke forsøkte i forbindelse med reformasjonsjubileet og landet på ordet «nåde». Få ord er mer sentrale i protestantisk teologi, men dette er det få spor av i medienes protestant-klisjeer.

På samme måte som populærprotestantene avviker fra religionsvitenskapens protestanter, avviker de også fra det bildet den største protestantiske kirken i Norge ønsker å tegne. I materialet er det kun én tekst som kommer i nærheten av temaet «nåde». Da Dagbladet skulle kåre lesernes mest populære sang av Alf Prøysen, vant visa «Du skal få en dag i mårå». I den anledning, og helt uten ytterligere referanse til kirke, teologi eller religion, ordla en prøysenkjenner seg slik: «Visas budskap om tilgivelse og det å få en ny sjanse er verdier det er lett å omfavne, og det er ikke rart en slik protestantisk grunntone resonnerer hos mange. ${ }^{{ }^{x i}}$ Som vi skal se, er det gjennomgående andre ting enn tilgivelse og nye sjanser som forbindes med protestantismens grunntone når klisjeen brukes $\mathrm{i}$ den offentlige samtalen. 


\section{Protestant-kategorier og gjennomgående trekk}

Med dette utgangspunktet i religionsvitenskap og teologi har jeg gått på jakt blant protestantismeklisjeene i en hermeneutisk og induktiv spiralbevegelse. I den første delen av analysen har jeg lett etter det som synes å være det avgjørende kjennetegnet ved protestanten eller det protestantiske i hver enkelt forekomst i materialet. Karakteristikkene er gruppert rundt de ulike forståelsene som finnes i teologien og religionsvitenskapen. Som allerede antydet, er en forståelse av protestantismen som tilsynelatende er inspirert av Weber, tallmessig dominerende. En forenklet, men anvendbar versjon av Webers tese er at protestantene kombinerte hardt arbeid med nøysomhet. Dermed ble det skapt et overskudd som kunne investeres i ny produksjon, og grunnlaget for kapitalismen var lagt. I grupperingen av klisjeene gir de to premissene hos Weber opphav til to kategorier av protestantisme-klisjeer: «Den hardtarbeidende protestanten» og «den nøysomme protestanten». Nøysomheten kan sees i sammenheng med en mer generell nøkternhet, og jeg kategoriserer og diskuterer noen forekomster av protestantisme-klisjeen som «den nøkterne og rasjonelle protestanten». I materialet grupperer også en del forekomster seg rundt temaene moral, skam og skyld. Jeg samler disse i kategorien «den skyldbevisste og moralske protestanten». Med utgangspunkt i den kirkelige koblingen av nåde og protestantisme, har jeg også sett etter «den tilgitte protestanten», men kun funnet det ene eksemplet som allerede er nevnt.

Spørsmålet om protestantismen er ektefølt og selvvalgt, som er så sentralt for blant annet Roy og Berger, går på tvers av disse kategoriene, siden den enkelte kan oppleve hardt arbeid, nøkternhet og streng moral som mer eller mindre selvvalgt. Dette blir dermed en annen variabel $\mathrm{i}$ analysen av hver enkelt tekst. Etter gjennomgangen av de ulike kategoriene av protestanter, spør jeg: Sier teksten noe om hvorvidt protestantismen er selvvalgt eller ikke, og i tilfelle hva? Svarene viser seg å tegne et tydelig bilde som går på tvers av Roys og Bergers idealprotestantisme. De trekker også oppmerksomhet til et annet gjennomgående trekk: Protestantisme-klisjeen knyttes ofte til det norske. Disse observasjonene blir utgangspunkt for den neste delen av analysen. Protestantismeklisjeen formidler ikke bare et saksinnhold, den har også en funksjon og inneholder ofte en implisitt

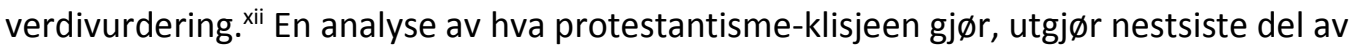
unders $\varnothing$ kelsen $f \varnothing r$ jeg til slutt spør etter hvordan protestantisme-klisjeen kobles til forestillinger om Gud.

\section{Webers protestant: hardtarbeidende og nøysom}


«Eneste grunn til at de fleste rike middelklassenordmenn jobber fra mandag til fredag formiddag, er at de sitter fast i en protestantisk arbeidsmoral kombinert med en overdreven materialisme og trangen til å opprettholde en småborgerlig fasade," skriver en spaltist i Dagsavisen. ${ }^{\text {xiii }}$ Slik fremhever han ett av de tydeligste trekkene i mediebildets protestantportrett. I én av fire tekster i utvalget karakteriseres protestanten ved hardt arbeid. Denne siden ved det protestantiske som 2000-tallets nordmenn «sitter fast i» satte sitt preg på 1900-tallets Norden, skal vi tro Aftenposten som i en omtale av en biografi om Astrid Lindgren beskriver hennes bakgrunn slik: «Astrid Lindgren representerte en legering av ulike idealer som strømmet gjennom Norden i løpet av 1900-tallet. Fra barndomshjemmet hadde hun en sterk, protestantisk arbeidsmoral og en vilje til å vedkjenne seg sine plikter. » $^{\text {iv }}$ Teksten for $\emptyset$ vrig berører verken protestantisme eller noe annet som har med religion å gjøre, og det later ikke til å være noe særegent ved Lindgren som er knyttet til protestantisme mer generelt. Det er nærliggende å tenke at journalisten kunne formidlet det samme saksinnholdet uten å bruke «protestantisk». Likevel gjør han det som for å gi litt ekstra farge - eller kanskje gjenkjennelse - til det svenske gårdbrukersamfunnet der den kjente forfatteren vokste opp for et århundre siden.

Karl Ove Knausgård er allerede introdusert som den norske erkeprotestanten. Også han omtaler arbeidsmoralen som forankret i det protestantiske, ${ }^{\mathrm{xv}}$ og en programleder i TV 2 beskriver seg selv slik overfor VG: «Jeg er en protestantisk arbeidssjel, rett og slett». I programlederens tilfelle fører denne protestantiske impulsen ifølge avisen til problemer om sommeren: Hun får seg ikke til å sette seg ned i sofaen, langt mindre legge seg, så lenge det er lyst ute. ${ }^{\text {vi }}$

I ytterligere omkring 10 prosent av tekstene møter vi den andre siden av Webers protestantisme, nøysomheten. En kjent investor, for eksempel, svarer slik i et intervju med Dagsavisen: «Er nøysomhet et ideal for deg? Ja, jeg er også fanget i den norske protestantiske tradisjonen. Jeg får dårlig samvittighet når jeg bruker penger.»xvii Spørsmålet om nøysomhet er foranlediget av at investoren påpeker at han ikke har privatfly, noe han kunne hatt råd til. Forestillinger om protestantisk nøysomhet av det mer hverdagslige slaget kommer til uttrykk slik hos en restaurantanmelder som referer denne indre dialogen etter at hovedretten er inntatt: «[Vi] er skikkelig fornøyde og så stinne at vi vurderer litt brennevin for å smelte maten. Men protestanten i oss sier nei, det er tross alt tirsdag.»xviii

Investering av overskudd er sentralt i Webers tese. I dagens Norge er Oljefondet det aller ypperste eksemplet på disponering av overskudd, selv om fondet ikke akkurat er en frukt av noen særegen norsk arbeidsmoral. Forbindelsen mellom Oljefondet og protestantisk arv dukker opp flere ganger. En blogger ordlegger seg slik overfor VG: 
Jeg tror at dagens nordmenn er mer et produkt av den protestantiske arven, enn vikingarven. Bare se på Oljefondet og hvordan det forvaltes. Tror du at en vikinghøvding som var vant med å plyndre landsbyer, og som hadde kommet over en formue lik Ekofisk-feltet, ville ha investert det på vegne av fremtidige generasjoner? Eller ville han ha brukt alle pengene på $\operatorname{mj} \varnothing \mathrm{d}$ ? ${ }^{\mathrm{xix}}$

En annen spaltist kommenterer Oljefondet slik: «Vi har gjort det eneste fornuftige. Spart penger til en regnværsdag. Den vi vet kommer. Vi har løst rikdommen på vårt norske, protestantiske vis og håndtert den som om den er et stort problem ${ }^{x \times}$

\section{Den rasjonelle og nøkterne protestanten}

Nøysomheten kan forstås som en side av en mer generell rasjonalitet og nøkternhet som har forbindelseslinjer til religionsvitenskapens beskrivelse av protestantismen som skeptisk til «utvendige» tegn på religion. Noe over en femdel av tekstene i utvalget (i tillegg til dem som er knyttet til nøysomhet og hardt arbeid) framviser den nøkterne og rasjonelle protestanten. En medisiner som argumenterer for kontrollert bruk av LSD beklager seg over «et snøskred av moraliserende $t \varnothing v$, godt ivaretatt av det protestantiske $n \varnothing k$ ternhetsidealet $i$ vår kulturarv. ${ }^{\star x i}$ Men protestantismen retter seg ikke bare mot rus, om vi skal tro protestantisme-analyser med opphav $\mathrm{i}$ legestanden. En annen medisinsk forsker forstår kampen mot antibiotikaresistens på liknende vis: «[V]i er nøkterne protestanter og har stort sett en sunn holdning...। Skandinavia ligger vi veldig godt an, fordi vi har brukt lite antibiotika.»xxii

Den protestantiske $n \varnothing k t e r n h e t e n$ er knyttet tett til en type rasjonalitet som gjør protestanten «innestengt». xxiii En slik streng rasjonalitet kan være grunnen til protestanten i klisje-utgave nekter seg ting, i noen tilfeller for å nyte senere: En kommentator i Aftenposten reflekterer over norsk friluftsliv: «Den protestantiske fjell-etikken er jo slik at du skal slite en del før du kan ha det bra. Å 'gå tur' er ingen spøk». xxiv VG skriver også om fjellet: «Det er noe typisk norsk eller protestantisk over slitet. I tusenvis av år har vi mestret kulde, lagret, planlagt, utsatt behov og samarbeidet om slått og bygging av nytt tak før frosten kom. ${ }^{\times \times v}$ Bare en uke senere fortolker VG også el-sykkelen $\mathrm{i}$ lys av protestantismen: «Det er mange nordmenn som fnyser av el-sykkel. Sykkel skal ha mosjonsaspekt. 
Det skal være god norsk protestantisk lidelse, svette og tungen som slips forbundet med å sykle til jobben. $)^{x \times v i}$

Morgenbladets «Etikeren», idehistorikeren Trond Berg Eriksen, advarer på sin side en innsender som har vunnet et større pengebeløp: «Jeg synes du plager deg selv unødig med klassisk protestantiske skrupler. Motsatt av hva du synes å tro, er ikke selvplageri i seg selv, moralsk sett, rosverdig.» Den protestantiske nøkternheten kan nok være uttrykk for en type rasjonalitet, men hva som oppfattes som rasjonelt, kan variere, minner Etikeren om, og deler et visdomsord «fra en langt heldigere kollega»: «Da jeg vant en million dollar...brukte jeg halvparten på vellevnet og løsaktige kvinner. Den andre halvdelen sløste jeg bort.»xxvii

Den særegne protestantiske rasjonaliteten, kan det se ut til, dreier seg om at følelsene ikke får overtaket. I stedet styres protestanten av plikten. En profilert samfunnsdebattant forteller at han aldri har «navet» fordi han «er oppvokst i en familie med en meget sterk protestantisk etikk». Heller ikke hos ham er det spor av tradisjonelt protestantisk kirkeliv i den konteksten som gis: «Min far var SF-er og studerte medisin ved det røde universitetet i München der han fikk med seg studentopprøret i -68. Det var Pax i bokhyllen hjemme. Ny Tid kom på døren».xxviii

Mange anerkjente samfunnsanalytikere beveger seg i grenselandet mellom klisje og mer velbegrunnet analyse når de refererer til protestantisme. Fredrik Sejersted påpeker i en kronikk om grunnloven at de nordiske landene deler «en felles protestantisk bakgrunn og pliktetikk.» ${ }^{\text {xix }}$ I en debatt om hva som styrer og bør styre norsk respons på Europas flyktningutfordringer, snakker Odin Lysaker om en «protestantisk pliktfølelse». ${ }^{x \times x}$ I en beslektet debatt, om NATOs krig i Libya, hevder Terje Tvedt derimot at debatten er preget av «sinnelagsetikkens totale herredømme» og får umiddelbart st $\varnothing$ tte (i samme artikkel) av Iver Neumann som utdyper: «Dette er en dypt protestantisk etikk, og vi må forstå den religiøs. Så lenge du i ditt hjerte vender det andre kinnet til, så kan du bombe så mye du vil. Det spiller ingen rolle om det går til helvete, så lenge du mente å gjøre det rette». ${ }^{x \times i}$ Det kan late til at uansett om man anser pliktetikk eller sinnelagsetikk å være dominerende i norsk offentlighet, så kan protestantismen gjøres til en del av forklaringen.

\section{Den skyldbevisste og moralske protestanten}

Verken dagens protestantiske kirker eller akademias utenfra-beskrivelser av protestantismen legger vekt på moral og skyldbevissthet som særlige protestantiske kjennetegn, men i undersøkelsen av protestantisme-klisjeen trenger denne beskrivelsen seg på. De spesifikke ordene «dårlig samvittighet» og «skam» forekommer i nær tilknytning til protestant-karakteristikker i mer enn hver 
tiende av tekstene i utvalget, og totalt faller omkring 30 prosent av forekomstene i kategorien «den skyldbevisste og moralske protestanten».

«Hva misliker du mest ved deg selv? - Det er min protestantiske dårlige samvittighet," svarer Johan Galtung i et intervju med Dagsavisen i anledning 85 -årsdagen. ${ }^{\text {xxxii }}$ Mer presist hva den består i, går ikke intervjuet inn på. Den dårlige samvittigheten kan være både en ren plage og en forklaring på andre handlinger, som når en spaltist i Morgenbladet spør om mange akademikeres interesse for «å snekre, brygge, lage, dyrke selv» skyldes «en protestantisk dårlig samvittighet som gjør at disse akademikerne ikke $t \varnothing r$ å være fullt ut akademikere». ${ }^{x x i i i}$ Den protestantiske skamfølelsen - og vi befinner oss vel å merke hele tiden i populærforestillinger, ikke i psykologiens analyser - kan knyttes til selvplageri og «å nekte deg selv noe du virkelig vil ha,»xxxiv eller som Aslak Sira Myhre analyserer sin egen analyse av professorers og forfatteres selvplaging i det som må være selvkritikk opphøyd i annen potens: «Kanskje er det min protestantiske etikk som snakker. Du skal være kritisk til deg selv, og det skal helst gjøre litt vondt. . ${ }^{x \times x v}$

Skam og dårlig samvittighet har oftest et ubestemt opphav når protestantismeklisjeen mobiliseres eller de knyttes til overtredelse av ganske allmenne forventninger om passende oppførsel, som i eksemplene over. Men populærprotestanten kan også mobiliseres i tilknytning til streng moral, både når det gjelder alkoholxxxi og seksualitet: «Hvordan er det mulig å finne så mye utroskap i dette landet, hvor protestantiske prinsipper om disiplin, skam og etikk holdes høyt?» spør en blogger med

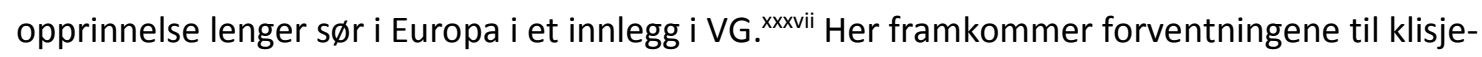
protestanten gjennom kontrasten - «utroskap». Det samme skjer i en bokomtale i Dagens Næringsliv: «Det er i det hele tatt noe befriende lite protestantisk med Blancas væremåte,» heter det om hovedpersonen som omgir seg med «eksmenn, elskere og sjøslag i værbitte sommergevanter» og har «et begjær som er like uhemmet som avslappet».xxxviii

\section{Selvvalgt protestantisme?}

Det overveldende flertallet av forekomstene av protestantisme-klisjeen i materialet, omkring ni av ti, passer i én av de fire kategoriene jeg har presentert så langt. Selv om bildet av populærprotestanten som dermed tegnes ikke er helt skarpstilt, er det ganske konsistent. Det er ingen påtrengende motsetning mellom å være arbeidsom, nøktern, rasjonell, moralsk og skyldbevisst. Dette bildet er et godt stykke unna Roy og Bergers idealprotestanter, men mye likner Webers. Hva så med et av de mest sentrale kjennetegnene ved religionsviternes protestantisme, idealet om at religionstilhørighet (altså protestantisme) skal være selvvalgt og ektefølt? Når det gjelder denne variablen, framstår 
protestantisme-klisjeen som Roys og Bergers protestants diametrale motsetning. I materialet jeg undersøker, finnes det ingen spor av den oppfatning at det personlige valg er sentralt i protestantidentiteten. Tvert imot er det en lang rekke eksempler på det motsatte. Forestillingen som stadig kommer til uttrykk er at personer «sitter fast»" ${ }^{x \times x i x}$ i sin protestantisme. Ekstra tydelig er det når noen bruker klisjeen til å karakterisere seg selv, noe som er tilfelle i omkring én av seks forekomster. Protestantismen er noe man er sosialisert inn i; den er kulturelt betinget og mer eller mindre ufrakommelig. Som en «indre stemme» ${ }^{\times l}$ opptrer protestanten som et freudiansk overjeg i et anstrengt forhold til den bevisste viljen og det frie valget. Som overjeg, kultur eller sosialisering er imidlertid denne protestantismen også noe man kan legge skylda over på når man ikke helt og fullt vil ta ansvar for sine «protestantiske» handlinger. Som en advokat sier om sitt valg av nattbordlektyre i et lett intervju med Dagens Næringsliv: «Kanskje en protestantisk arv? Kan ikke ha det for bra? Haha, ja, man er jo resultat av kulturen man lever i.» xi

Dermed er vi også ved et annet, nært beslektet, fellestrekk ved svært mye av bruken av protestantklisjeen: Den karakteriserer det norske eller nordiske, slik vi allerede har sett flere eksempler på. I noen situasjoner er «protestant» bare en vag markør for å tilhøre den norske flertallsbefolkningen, ${ }^{\text {xlii }}$ men oftere bidrar det til å knytte de bildene av protestanten jeg har tegnet over, eksplisitt til det norske. En Dagblad-spaltist observerer joggende nordmenn i kroatiske bygater og gjør seg følgende refleksjon om det artsspesifikt norske: «Vi tenkte at ikke en gang på ferie kan nordmannen motstå fristelsen til å pine seg selv. Hva er det artsspesifikke ved oss? Den protestantiske etikk, den kan vi ikke løpe fra». ${ }^{\text {liii }}$

Bruken av protestantisme-klisjeen til å karakterisere det norske blir særlig påfallende i to tilfeller der den brukes til å etablere en kontrast mellom norske forhold og USA uten blikk for at det ellers er vanlig å regne med at protestantismen har preget amerikansk kultur på en avgjørende måte. ${ }^{\text {liv }}$ Men også et annet eksempel over, som knyttet protestantiske kjennetegn til norske forhold «i tusenvis av år», viser at klisjeen kan karakterisere det norske ganske løsrevet fra de beskrivelsene som religionsforskere og teologer vil underskrive på. .lv

\section{Protestantens motsetning}

Ord og begrepet fungerer ikke minst ved at det etableres kontraster til andre ord og begreper. ${ }^{\text {xlvi }}$ । mange av eksemplene i materialet er den sentrale funksjonen å framheve klisjeprotestantismens motsetning, ikke minst synes dette å gjelde når protestantisme knyttes til streng moral. I ett tilfelle kontrasteres «protestantisk barnetro» med «begeistret vilje til seksuell overskridelse». ${ }^{\text {lvii }}$ I et annet 
stilles «den gamle protestantiske tradisjonen vi bærer på» opp mot «sydlandsk begjær». xviii Det seksuelle begjæret, som protestanten har lite rom for, knyttes her eksplisitt til geografi, til «det sydlandske». Det skjer også i enda en ganske parallell forekomst, der erke-protestanten Knausgård får representere den ene polen i en oppstilt motsetning: «I stedet for Knausgårds nordiskprotestantiske selvforakt, er det et kontinentalt selskapsmenneske som trer fram.» ${ }^{\text {klix }}$

I svært mange av de konvensjonelle referansene til protestanter eller protestantisme som jeg sorterte ut i denne undersøkelsen, etableres en implisitt - og ofte eksplisitt - kontrast til andre kristne tradisjoner, oftest til katolisismen. Når det gjelder protestantisme-klisjeen som unders $\varnothing$ kes her, er bildet annerledes. Det kontinentale eller sydlandske (romanfiguren Blanca som er nevnt over, er for øvrig spansk), er saklig sett katolisismens sted som kan kontrasteres med det protestantiske nord. Likefullt er det svært sjeldent et tydelig bilde av en katolikk som trer fram i kontrastene. Det ville være noe som skurret hvis det i stedet for «kontinentalt» eller «sydlandsk» sto «et katolsk selskapsmenneske» eller «katolsk begjær». Det katolske kan nok klinge med, men trenger seg ikke på som klisjeens kontrast. Tvert imot må vi spørre om ikke en del av de karakteristikkene som i Norge tillegges populærprotestanten, som streng moral og skamfølelse, like gjerne kunne vært knyttet til en katolisisme-klisje dersom Den katolske kirke historisk hadde vært den viktigste religiøse tradisjonen i Norge. Trolig er det den dominerende religiøse tradisjonen som oppfattes som kilde til streng moral og skyldfølelse, mens alternativet ikke er en annen tradisjon, men en «frigjøring» fra den. Interessant nok er slik «frigjøring» fra tradisjonelle normer noe som både av religionsvitere og protestantiske teologer anses å være typisk protestantisk. Det finnes det få spor av i materialet.

Tross et lite innslag av tvetydighet kommer det protestantiske gjennomgående negativt ut $\mathrm{i}$ sammenlikning med det seksuelt mer frigjorte «sydlandske» $i$ alle sammenlikningene som berører seksualmoral, og som vel å merke i alle tilfeller er knyttet til litteratur. Klisjeprotestanten representerer noe gammeldags og bakstreversk. I en annen type kontrast som det finnes en del av i materialet, tilhører protestanten også fortiden, men som en motsetning til negative trekk i samtiden. En skribent i Morgenbladet kontrasterer Webers protestantiske ånd for et århundre siden med dagens situasjon der «den kapitalistiske 'ånden' er selvrealisering, og i likhet med protestantismen bidrar den til systemets overlevelse og vekst». Motsetningen, som understreker mange av elementene i protestantisme-klisjeen, utdypes i forklaringen som følger: «Hos Weber var veksten avhengig av en fornuftsstyrt, langsiktig mann. I dag ligger lønnsomheten i en følelsesstyrt og flyktig kvinne.»'En tilsvarende analyse bragte den samme skribenten til torgs knappe to år tidligere: «Med sine hedgefond-forvaltere, sine shortsalg og sin totale endringsvilje er kapitalismen så lite protestantisk som den kan få blitt. Asketen er borte, konsumenten er hovedperson i den nye $\varnothing$ konomien. $)^{\text {li }}$ 


\section{Protestantismen, god eller dårlig?}

Dermed er vi ved et viktig spørsmål: Hvilke verdivurderinger knytter seg til bruken av protestantklisjeen; er populær-protestantisme noe godt eller noe dårlig? Berger og Roy er, hver på sin måte, opptatt av at religion i moderne samfunn overtar stadig flere typiske trekk fra protestantismen. I forskningsprosjektet «Good Protestant, bad religion?» ved Det teologiske fakultet er denne observasjonen utgangspunktet for å spørre om myndighetenes regulering av religion og den alminnelige offentlige samtalen i Norge og andre vestlige land har som uuttalt forutsetning at protestantisme er den gode normen, mens annen religion møtes med mistenksomhet. ${ }^{\text {lii }}$

Når det gjelder de forestillingene som mobiliseres av protestantisme-klisjeen i mediene, er bildet tvetydig. I noen tilfeller brukes merkelappen «protestantisk» med tydelig positivt fortegn.

Statsminister Erna Solberg er den mest prominente representanten for slik god-protestantisme i det materialet jeg undersøker. I løpet av en uke i juni 2015 brukte hun svært representative protestantklisjer offentlig to ganger. I et intervju pekte hun på «en god protestantisk etikk» som en av

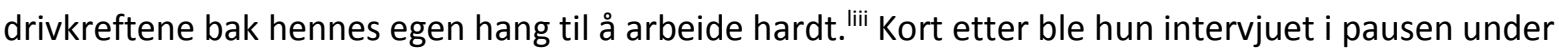
en fotballkamp der favorittlaget Brann enda en gang gjorde det dårlig: «Det er litt vondt. Samtidig er det den testen man skal gjennom, er det ikke det? Med vår protestantiske legning så skal vi jo lide litt før man vinner. $)^{\text {liv }}$

I analysen av materialet har jeg kategorisert forekomstene av protestantisme-klisjeen utfra om den umiddelbart gir en positiv, nøytral eller en negativ evaluering av det som beskrives. Fordelingen er svært jevn: 35 prosent av forekomstene havner i kategorien positiv. Ved siden av en del referanser til hardt arbeid, nøysomhet og nøkternhet faller mange henvisninger som knytter protestantisme til fornuft og rasjonalitet, i denne kategorien. Nøyaktig like stor andel forekomster faller i kategorien negativ evaluering. De fleste av eksemplene knyttet til moral og skamfølelse hører til her. De resterende 30 prosent er nøytrale.

Mange tekster er imidlertid vanskelige å kategorisere, og det som på overflaten kan framstå som anerkjennelse eller avvisning av det protestantiske, kan i noen tilfeller ha motsatt funksjon. Få forekomster er så entydig positive som statsministerens omfavnelse av egen protestantisk arbeidsetikk over. Oftere bidrar klisjeen til å skape en viss distanse mellom taleren og det kulturelle feltet som karakteriseres. Når en spaltist i en slentrende tekst om nyttårsforsetter sier at «[d]en indre, svært konservative protestanten av en indre stemme har sagt noe sånt som dette: Ikke drikke alkohol ut januar», ${ }^{\text {V }}$ er det naturligvis ingen påstand om at han styres av indre stemmer i noen 
patologisk forstand. Det retoriske grepet brukes til å minne om en kulturell strømning, avholdstanken forankret i kristne miljøer, som implisitt kritiseres ved at det skapes en distanse. Samtidig gjenstår en ambivalens, for spaltisten følger det protestantiske påbudet. Det likner på Knausgårds beskrivelse av sin protestantiske selvfornektelse som jeg siterte i innledningen: Protestantisme-klisjeen blir brukt kulturkritisk, men signaliserer også at taleren identifiserer seg med denne kulturen. Dette flertydige, både i materialet som helhet og i mange av enkeltforekomstene av klisjeen, tyder på at selve ordet «protestant» eller «protestantisk» i seg selv skaper både positive og negative assosiasjoner i den offentlige samtalen. Det oppfattes ikke uten videre slik at protestanten er god, mens annen religiøsitet er dårlig.

\section{Gud?}

Den dominerende protestantiske kirken i Norge, Den norske kirke, valgte «nåde» som nøkkelord da reformasjonen skulle feires. Som nevnt, finnes det i hele materialet kun ett tilfelle der klisjeprotestantisme knyttes til noe som likner nåde. Men hva så med subjektet for denne protestantiske nåden, Gud? Spiller Gud noen rolle i tilknytning til bruken av klisjeen protestant og protestantisme? Svaret er entydig: nei.

Et av utvalgskriteriene i unders $\emptyset$ kelsen er at henvisning til protestanter eller protestantisme ikke skal være helt teologisk konvensjonell. Altså faller henvisninger for eksempel til «protestantiske kirker» eller «protestantiske prester» stort sett utenfor. Det samme gjør (de svært få) faglig funderte redegjørelsene for protestantisk teologi. Ut fra unders $\varnothing$ kelsens design er det derfor ikke overraskende at tekster som i liten grad forholder seg til teologi eller religion vil dominere. Det er imidlertid ikke noe prinsipielt i veien for at den mer klisjepregete bruken av «protestant» eller «protestantisme» kunne opptre i sammenhenger som også inneholdt henvisninger til Gud eller religiøse forestillinger. Derfor er det verdt å legge merke til at forestillinger om Gud er nærmest fraværende i materialet. Som undersøkelsen viser, er populærprotestanten både henfallen til hardt arbeid, $n \varnothing k$ ternhet, $n \varnothing y s o m h e t$ og streng moral som implisitt, gjennom henvisningen til protestantisme, forutsettes å ha opphav i religiøse forestillinger. Imidlertid er det knapt noen eksempler i materialet som direkte knytter slike egenskaper til en gudstro, enn si til gudsfrykt, slik tradisjonell protestantisme i noen grad har gjort. I en tredel av materialet blir navngitte enkeltpersoner knyttet til protestantisme, men det forekommer ingen eksempler på at tekstene berører disse personenes eventuelle trosoverbevisninger, og det finnes ingen antydninger om at de protestantiske karaktertrekkene har opphav i personlige forestillinger om en streng Gud. 
I de tilfellene der skyldfølelse og skam knyttes til konkrete handlinger, er det heller ikke en typisk konservativ protestantisk moral (for eksempel seksualmoral eller alkoholbruk) som kommer til uttrykk. Snarere dreier det seg om slikt som reguleres av ganske allmenn moral eller moralisering som latskap, å spise eller drikke mye eller sløse med penger. Det er ingen tegn i tekstene på at det er frykt for «hva Gud vil si» som driver den indre protestantiske stemmen.

\section{Konklusjon: Nøysomhet uten gudsfrykt}

Protestanten er ingen hyppig gjest i norske avisspalter, i hvert fall ikke som klisje av den typen jeg har lett etter her. Tidvis kan det gå flere uker mellom hver gang hun eller han opptrer. Likevel dukker protestanten opp ofte nok til at det til sammen tegnes et bilde av hvilke assosiasjoner som mobiliseres i den brede offentligheten når ordene «protestant», «protestantisk» eller «protestantisme» brukes. Som karakteriserende klisjé benyttes protestantismen til å forklare praksis og holdninger i møte med alt fra antibiotika og oljepenger til el-sykler og lottogevinster. Et overordnet inntrykk er at protestanten er webersk og kjedelig, men om det er en god eller dårlig egenskap, kan variere.

Det kan synes som det er et stort gap mellom det religionsforskere og teologer vektlegger som typisk protestantisk, og de assosiasjonene ordet skaper blant vanlige norske språkbrukere. De protestantiske kirkenes forkynnelse av nåde og tilgivelse har satt svært få avtrykk i de populære forestillingene om protestantisme. Og mens religionsvitenskapens protestantisme karakteriseres av personlig trosoverbevisning, å være selvvalgt og i stor grad tilhøre privatsfæren, synes de populære forestillingene om det typisk protestantiske snarere å være frikoblet fra personlig overbevisning og kanskje nettopp derfor å være noe individer sosialiseres inn i, enten de vil eller ikke. Derfor utspiller det typisk protestantiske seg også i den offentlige sfæren like mye som i privatsfæren.

På ett punkt nærmer forskningens forestillinger om protestantisme seg klisjeens protestant. En del religionsforskere argumenterer for at protestantismen også bærer i seg en impuls til sekularisering. Hvis noe kjennetegner alle versjonene av protestantismeklisjeen, så er det nettopp at de er sekulære: De inneholder ikke spor av levende tro på noen gud. Snarere framstår de som en form eller et avtrykk som religionen - protestantismen - har avsatt i samfunnet før den har trukket seg tilbake og forsvunnet ut av synet. Protestantiske dyder, antyder protestantklisjeene, er overtatt av allmennmoralen helt uten henvisning til de trosforestillingene som eventuelt ga opphav til dem. Det tegnes et bilde av en protestant som er arbeidsom og nøktern, men som knapt nok har noen gud å frykte. 


\section{Litteratur}

Austin, J.L., How to do Things with Words: The William James Lectures Delivered at Harvard University in 1955. Harvard University Press, Cambridge (Massachusetts) 1962

Berger, P.L., "Pluralism, Protestantization, and the Voluntary Principle" i Thomas Banchoff (red.), Democracy and the New Religious Pluralism, Oxford University Press, Oxford 2007

Fairclough, N., Discourse and Social Change. Polity Press, Cambridge 1992

Joas, H., Faith as an Option: Possible Futures for Christianity, Stanford University Press, Stanford 2014

Roy, O., Holy Ignorance: When Religion and Culture Part Ways. Hurst, London 2010

Tully, J. (red), Meaning and Context: Quentin skinner and His Critics, Polity Press, Oxford, 1988

Weber, M., The Protestant Ethic and the Spirit of Capitalism, Routledge, London 1992 [1930]

$\emptyset$ stbye, H., Helland, K., Knapskog, K., Larsen, L.O., og Moe, H., Metodebok for Mediefag. 4. utg., Fagbokforlaget, Bergen 2013

\footnotetext{
' I denne undersøkelsen står klisjeene i sentrum, ikke de personene som bruker dem eller eventuelt karakteriseres gjennom dem. Jeg vil derfor stort sett ikke nevne de som har skrevet tekstene eller er omtalt ved navn når jeg gjengir eksempler, men det er lett å finne dem ved å gå til kildene som er oppgitt. Jeg gjør unntak for noen få svært kjente personer samt enkelte akademikere der kjennskap til kilden er viktig for å forstå eksemplet.

ii Dagbladet 12.07.2014

iii Avisene er valgt blant de største avisene (etter opplagstall) når man holder de typiske regionavisene utenfor. Avisene Vårt Land og Dagen er med hensikt ikke tatt med. Målet har vært å studere den allmenne forståelsen av protestantisme, ikke den mer spesialiserte, religionsfaglig eller teologisk funderte bruken som jeg ventet å finne mer av i disse avisene. Etter at unders $\varnothing$ kelsen ble gjennomf $\varnothing r t$, er Dagens Næringsliv fjernet fra Atekstdatabasen. Tekstene fra denne avisen kommer altså ikke opp i nye søk i basen. Opplagstall for norske aviser finnes her: http://www.medienorge.uib.no/statistikk/medium/avis/190

iv Dette er ikke først og fremst en kvantitativ undersøkelse med presise beregninger av antall og prosenter. Likevel er det et poeng å si noe om hvor hyppig ulike forståelser av protestantismen forekommer i materialet. Derfor angir jeg blant annet hvordan tekstene fordeles prosentvis på ulike kategorier. Jeg oppgir gjennomgående omtrentlige tall. Det skyldes at det er et visst rom for tolkning og skjønn også i beregningen av antall tekster for eksempel når en avis siterer en annen og når forsidehenvisninger bruker litt andre ord enn det som forekommer i hovedteksten. Av disse grunner, så vel som av den usikkerheten som følger av det subjektive tolkningsskjønnet, har det liten hensikt å operere med tall som gir inntrykk av å være mer presise enn unders $\varnothing$ kelsen gir grunnlag for. Se for $\varnothing v$ vrig ( $\varnothing$ stbye m.fl., ss. 208-11).

${ }^{\vee}$ Aftenposten 14.03.2017

vi (Berger, ss. 19-20)

vii (Roy, s. 197)

viii Se for eksempel (Joas, ss. 52-59)

ix (Weber 1992)

x Klassekampen 09.07.14

xi Dagbladet 29.07.14

xii se (Austin 1962) og (Tully 1988)

xiii Dagsavisen 17.02.15

${ }^{\text {xiv }}$ Aftenposten 31.05.15

${ }^{x v}$ Klassekampen 26.07.14

xvi VG 30.07.16

xvii Dagsavisen 09.05.15

xviii Dagsavisen 25.04.15
} 
xix VG 27.09.15

${ }^{x x}$ Dagsavisen 31.10.15

xxi Dagbladet 02.11.16. Den samme medisineren bruker en nærmest identisk uttrykksmåte i Aftenposten 17.06.15

xxii Morgenbladet 02.09.16

xxiii VG 10.10.14

xxiv Aftenposten 12.10 .14

${ }^{x \times v}$ VG 19.04.14

xxvi VG 26.04.14

xxvii Morgenbladet 31.10 .14

xxviii Dagens Næringsliv 14.11 .15

xxix Aftenposten 21.08.14

xxx Morgenbladet 22.05.15

xxxi Klassekampen 18.09.15

xxxii Dagsavisen 24.10.15

xxxiii Morgenbladet 21.11.14

xxxiv Dagbladet 19.06.15

xxxv Dagens Næringsliv 26.06.16

xxxvi Dagsavisen 10.01.15

xxxvii VG 28.12.16

xxxviii Dagens Næringsliv 07.05.16

xxxix Kfr. Dagsavisen 17.02.15, også sitert over

xl Dagsavisen 10.01.15, se også note lv

xli Dagens Næringsliv 03.03.15

xlii Dagbladet 28.01.17

xliii Dagbladet 06.10.14

xliv Klassekampen 07.02.15 og Morgenbladet 02.09.16, også sitert over

xlv VG 19.04.14

xlvi (Fairclough ss. 190-94)

xvvii Morgenbladet 06.05.16

xlviii Dagbladet 05.04.16

xlix Klassekampen 17.10 .15

' Morgenbladet 28.10.16

li Morgenbladet 23.01.15

lii Se prosjektets nettside: http://www.tf.uio.no/english/research/projects/goba/

liii «Politisk kvarter» på NRK P» 24. juni, gjengitt i Aftenposten 03.07.15

liv Dagbladet 30.06.15

${ }^{\text {Iv }}$ Dagsavisen 10.01.15 